\title{
Chapter 7 \\ Grain Yield Responses of Selected Crop \\ Varieties at Two Pairs of Temperature \\ Analogue Sites in Sub-humid and \\ Semi-arid Areas of Zimbabwe
}

\author{
Justice Nyamangara, Esther N. Masvaya, Ronald D. Tirivavi \\ and Adelaide Munodawafa
}

\begin{abstract}
Climate analogues, based on 30 years meteorological data, were identified in smallholder areas of Zimbabwe. The sites were Kadoma (722 mm annual mean rainfall; $21.8{ }^{\circ} \mathrm{C}$ annual mean temperature) which was the higher temperature analogue site for Mazowe $\left(842 \mathrm{~mm}\right.$ annual mean rainfall; $18.2{ }^{\circ} \mathrm{C}$ annual mean temperature) for wetter areas, and Chiredzi (541 $\mathrm{mm}$ annual mean rainfall; $21.3{ }^{\circ} \mathrm{C}$ annual mean temperature) which was the higher temperature analogue site for Matobo $\left(567 \mathrm{~mm}\right.$ annual mean rainfall: $18.4{ }^{\circ} \mathrm{C}$ annual mean temperature) for drier areas. At each site and for each crop, three varieties were laid out in a randomized complete block design with three replications. The trials were conducted for two seasons (2011/2012 and 2012/2013). Maize and groundnut yields were higher at the cooler and wet sites and decreased significantly at the warmer and dry sites. In case of sorghum and cowpea, yields at the hotter site remained high implying that these crops are more tolerant to warmer temperatures predicted for 2050. At the drier sites, yields for all crops were significantly lower at the hotter site implying that crop production in the 2050s climate of the cooler site will be more difficult. The hypothesis that with increasing surface temperatures in a climate change scenario short duration genotypes can perform better compared with long duration was not confirmed.
\end{abstract}

Keywords Climate change - Crop varieties - Food security - Rainfall pattern • Temperature

\footnotetext{
J. Nyamangara $(\bowtie) \cdot$ E.N. Masvaya $\cdot$ R.D. Tirivavi

International Crops Research Institute for the Semi-Arid Tropics (ICRISAT),

Matopos Research Station, P.O. Box 776, Bulawayo, Zimbabwe

e-mail: j.nyamangara@cgiar.org
}

\begin{abstract}
A. Munodawafa
Department of Land and Water Resources Management, Faculty of Natural Resources

Management and Agriculture, Midlands State University, Private Bag 9055, Gweru,

Zimbabwe
\end{abstract}

(C) Springer International Publishing Switzerland 2015

W. Leal Filho et al. (eds.), Adapting African Agriculture to Climate Change,

Climate Change Management, DOI 10.1007/978-3-319-13000-2_7 


\section{Introduction}

Crop productivity and food systems are predicted to be affected by changing climate which is likely to affect crop variety preferences by farmers across varying agro-ecological regions in future (Gregory et al. 2005). In Zimbabwe, conditions for growing early maturing and relatively lower yielding maize varieties are projected to shift more into currently wetter regions experiencing changing conditions suitable for growing long duration and relatively higher yielding varieties (Nyabako and Manzungu 2012). Reduction of crop yields is likely to result in a fall in crop revenue by as much as $90 \%$ (Carter et al. 2007). The changes in crop production patterns are more likely to affect the marginalized smallholder farmers, who already experience low productivity due to current socio-economic and biophysical challenges characterizing the drier areas of sub-Saharan Africa (SSA) thereby impacting negatively on food security (Matarira et al. 1995). These predicted changes call for a focus on adaptive cropping strategies that will serve as mitigation measures against drastic changes in smallholder farmers' livelihoods (Eriksen et al. 2011).

Exposing smallholder farming communities to various crop variety options than those they traditionally grow might be a way forward in preparing them for the future. Days to maturity vary from crop to crop and are influenced by crop genotype, climatic and environmental factors (Bruns 2009). As the conditions in the wetter areas get drier and warmer, it is important for farmers to realize that they can no longer continue to grow high yielding crop varieties that take long to mature but rather should move to shorter duration varieties to ensure food security. Although crop yields are predicted to fall by adoption of shorter season varieties, the quantum is expected to be lower compared with that from continuing to grow longer season varieties which can completely fail to mature if the rainy season ends prematurely as predicted to happen more frequently in much of SSA in future.

It is against this background that trials to assess the grain yield of selected varieties of four crops were established at two pairs of analogue sites (wetter and drier) differing in temperature $\left(2-4{ }^{\circ} \mathrm{C}\right)$ but with similar rainfall patterns. The crops were selected based on farmer preferences and suitability to different climatic conditions whilst the varieties were selected based on the number of days to maturity. It was hypothesized that as temperature increases in climate change scenario, shorter duration crop varieties will substitute longer duration varieties.

\section{Materials and Methods}

\section{Site Description}

The trials were conducted at two climate analogue sites. The wetter pair was Mazowe (cool/wet, $842 \mathrm{~mm}$ annual rainfall; $18.2{ }^{\circ} \mathrm{C}$ annual mean temperature) and Kadoma (hot/wet, $722 \mathrm{~mm}$ annual rainfall; $21.8{ }^{\circ} \mathrm{C}$ annual mean temperature), and 


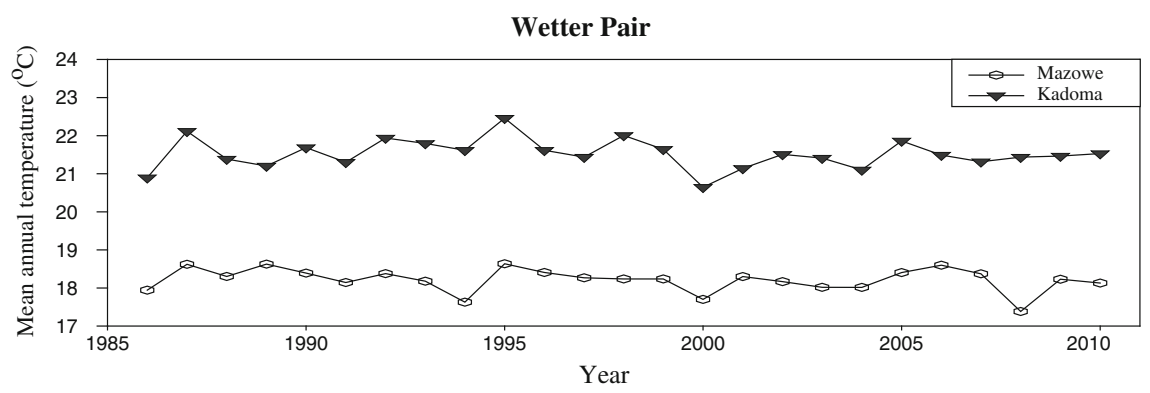

Drier Pair

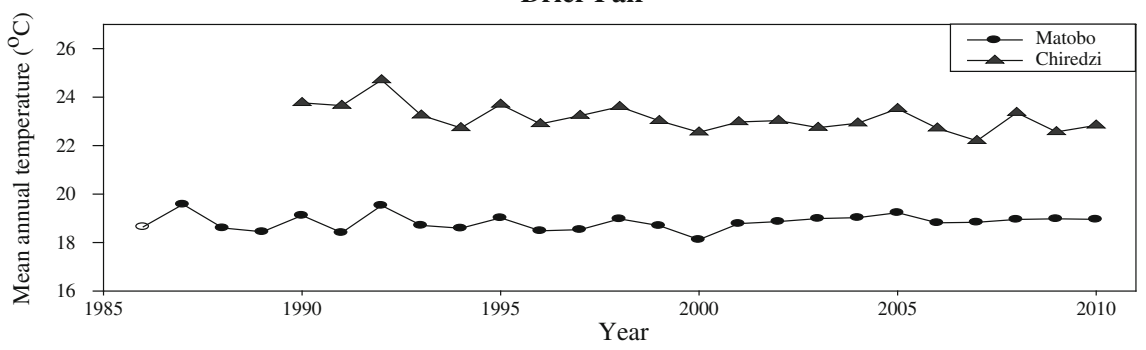

Fig. 7.1 Long-term temperature variability at the wetter and drier analogue pairs used for the study

the drier pair was Matobo (cool/dry, $567 \mathrm{~mm}$ annual rainfall: $18.4{ }^{\circ} \mathrm{C}$ annual mean temperature) and Chiredzi (hot/dry, $541 \mathrm{~mm}$ annual rainfall; $21.3{ }^{\circ} \mathrm{C}$ annual mean temperature). Inter-annual mean temperature variability at the four sites is presented in Fig. 7.1. The soils at Mazowe and Kadoma sites are red clays derived from dolerite and are relatively more weathered and leached. The soils at the Matobo site are loamy sands derived from granite rocks and those from Chiredzi are sandy loams derived from a mixture of siliceous gneiss and mafic rocks.

\section{Experimental Design, Management and Data Collection}

A completely randomized block design is employed with each of the crop varieties replicated three times. The trials were implemented for two seasons (2011/2012 and 2012/2013). The crop varieties used in the trials are given in Table 7.1. Soil samples $(0-0.15 \mathrm{~m})$ were collected at the beginning of the first season $(2011 / 2012)$ from three sites for laboratory testing and the results are presented in Table 7.2. The experimental sites were tilled using a tractor drawn plough before planting and red clay soils at Mazowe and Kadoma were also disked to break large clods. Maize was planted at a spacing of $0.9 \mathrm{~m} \times 0.3 \mathrm{~m}\left(37,037\right.$ plants ha $\left.^{-1}\right)$, sorghum $0.75 \mathrm{~m} \times 0.2 \mathrm{~m}$ $\left(66,667\right.$ plants ha $\left.{ }^{-1}\right)$, and groundnut and cowpea $0.45 \mathrm{~m} \times 0.15 \mathrm{~m}(148,148$ plants $\left.\mathrm{ha}^{-1}\right)$. Plot sizes were $6.5 \mathrm{~m}$ by $6.5 \mathrm{~m}$ and yield was determined from $4 \mathrm{~m}$ by $4 \mathrm{~m}$ 
Table 7.1 Crop varieties

\begin{tabular}{l|l|l|l}
\hline \multirow{2}{*}{ Crop } & Varieties & Medium maturing & Late maturing \\
\cline { 2 - 4 } & Early maturing & SC513 & SC727 \\
\hline Maize & SC403 & SDSL89473 & Pato \\
\hline Sorghum & Macia & Natal common & Makhulu red \\
\hline Groundnut & Nyanda & CBC2 & Landrace \\
\hline Cowpea & CBC1 &
\end{tabular}

Table 7.2 Soil characterization on analogue and reference sites

\begin{tabular}{l|l|l|l|l|l|l}
\hline Site & $\begin{array}{l}\mathrm{pH}(1 \mathrm{M} \\
\left.\mathrm{CaCl}_{2}\right)\end{array}$ & $\begin{array}{l}\text { Olsen-P } \\
\left(\mathrm{mg} \mathrm{kg}^{-1}\right)\end{array}$ & $\begin{array}{l}\text { Total P } \\
(\%)\end{array}$ & $\begin{array}{l}\text { Mineral N } \\
\left(\mathrm{mg} \mathrm{kg}^{-1}\right)\end{array}$ & $\begin{array}{l}\text { Total N } \\
(\%)\end{array}$ & $\begin{array}{l}\text { Organic } \\
\mathrm{C}(\%)\end{array}$ \\
\hline Matobo & 5.3 & 0.1 & 0.01 & 3.7 & 0.04 & 0.8 \\
\hline Mazowe & 5.6 & 0.5 & 0.1 & 2.4 & 0.1 & 1.6 \\
\hline Kadoma & 6.1 & 0.5 & 0.04 & 3.7 & 0.1 & 1.3 \\
\hline
\end{tabular}

net plots. Maize and sorghum were fertilized with 300 and $286 \mathrm{~kg} \mathrm{ha}^{-1}$ basal fertilizer $(7 \% \mathrm{~N}: 6 \% \mathrm{P}: 6 \% \mathrm{~K})$ for the wetter and drier sites respectively and a top dressing fertilizer rate of $150 \mathrm{~kg} \mathrm{ha}^{-1}(34.5 \% \mathrm{~N})$ was applied at 4-6 weeks after planting depending on rainfall pattern. Groundnut and cowpea received similar basal rates to maize and sorghum but were not top-dressed with $\mathrm{N}$ fertilizer; gypsum was applied to groundnut at flowering at $250 \mathrm{~kg} \mathrm{ha}^{-1}$.

All the plots were weeded three times each season using hand-hoes with the first weeding performed two weeks after planting. Armyworm (Spodoptera exempta) and other leaf eaters were controlled by spraying carbryl (1-naphthyl methylcarbamate) $85 \%$ WP. Aphids were controlled in cowpea by spraying diamethoate $(\mathrm{O}$, O-Dimethyl S-(N methylcarbamoylmethyl) phosphorodithioate). Harvesting was done at physiological maturity and yields were adjusted to moisture content by 10 and $12.5 \%$ for legumes and cereals, respectively.

\section{Statistical Analysis}

Grain yields were analyzed using analysis of variance (ANOVA) in GenStat 14th edition (2011). The standard error of differences (SED) of the means $(P<0.05)$ was used to separate site and variety means.

\section{Results}

Figure 7.2 shows that in the first season (2011/2012) Matobo received the least amount of rainfall which was $66.5 \%$ lower than the hotter analogue pair (Chiredzi). In the second season Kadoma received $74.7 \%$ lower rainfall than the cooler 

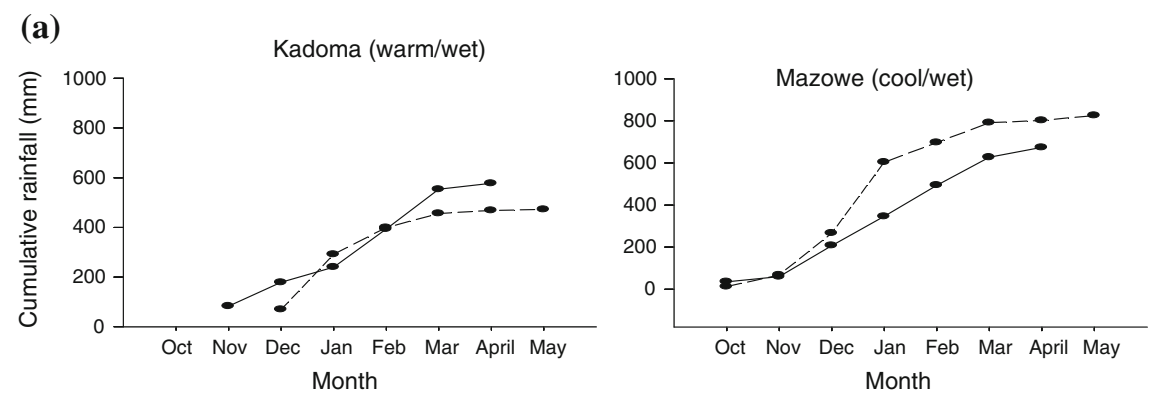

(b)
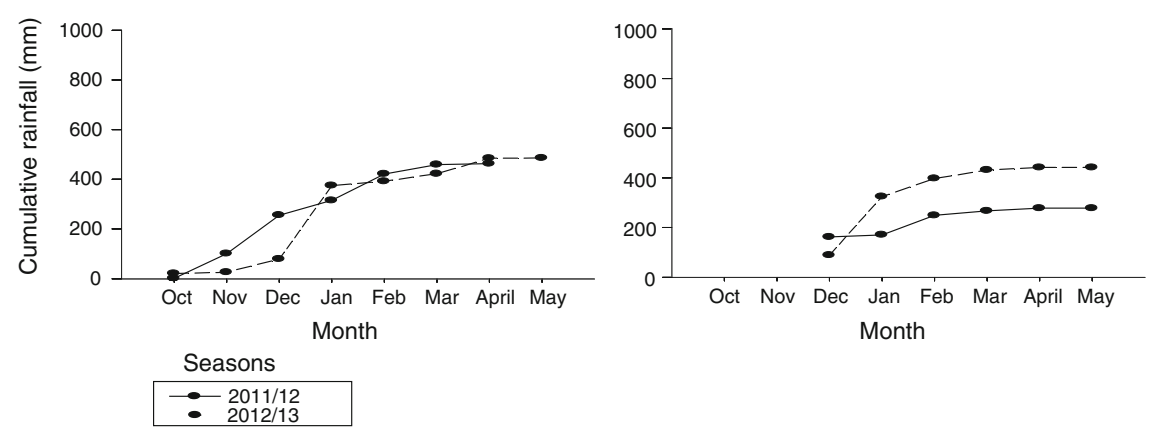

Fig. 7.2 Cumulative monthly rainfall recorded at the wetter and drier analogue sites during 2011/ 2012 and 2012/2013 cropping seasons. a Warm/wet and cool/wet analogue sites. b Warm/dry and cool/dry analogue sites

analogue pair (Mazowe) while the difference between the drier analogue pair was only $9.9 \%$. The soils from Mazowe and Kadoma were relatively more fertile as shown by higher $\mathrm{pH}$, soil organic carbon and total nitrogen compared with Matobo (Table 7.2). Soil samples were not collected at the start of the first cropping season in Chiredzi.

\section{Grain Yields at the Wetter Analogue Pair}

In the first season maize yields followed the order long $>$ short $>$ medium season but the varietal differences were not significant (Table 7.3). In both seasons, maize yields were significantly higher $(P<0.001)$ at the cooler site (Tables 7.3 and 7.4). However, in the second season, varietal differences and variety by site interaction were significant $(P<0.01)$. The medium season variety (SC513) achieved the lowest yields in both seasons. The results implied a reduction in maize yield as 
Table 7.3 Maize and sorghum grain yields at Kadoma (hot/wet) and Mazowe (cool/wet), Zimbabwe in the 2011/2012 season

\begin{tabular}{l|l|l|l|l|l|l}
\hline & \multicolumn{4}{l}{ Maize yield $\left(\mathrm{kg} \mathrm{ha}^{-1}\right)$} & \multicolumn{3}{l}{ Sorghum yield $\left(\mathrm{kg} \mathrm{ha}^{-1}\right)$} \\
\cline { 2 - 7 } & SC403 & SC513 & SC727 & Macia & SDSL89473 & Pato \\
\hline Kadoma & 3,373 & 2,529 & 3,979 & 3,121 & 5,468 & 3,928 \\
\hline Mazowe & 5,083 & 4,857 & 5,937 & 5,223 & 2,007 & 3,861 \\
\hline & & $P$ value & SED & \multicolumn{2}{l}{$P$ value } & SED \\
\hline Site & 0.005 & 547.1 & \multicolumn{2}{l}{0.088} & 251.7 \\
\hline Variety & 0.198 & 672.0 & 0.396 & 308.2 \\
\hline Interaction & 0.902 & 952.3 & $<0.001$ & 435.9 \\
\hline
\end{tabular}

temperature increases, especially in the first season when rainfall amount between the cooler and hotter sites was comparable (Fig. 7.2).

In the first season sorghum yields were varying between sites and varieties but the interaction between site and variety was significant $(P<0.001)$ (Table 7.3). The short season variety achieved the highest yield at the cooler site while the medium season variety achieved the highest yield at the hotter site (Table 7.3), and the trend was reversed between the sites in the second season (Table 7.4). In the second season, in addition to varietal differences site and variety interaction was also significant. The results imply that sorghum yield was less affected by higher temperature, even in a low rainfall season, and therefore was more resilient and more suitable (than maize) to predicted higher temperature conditions by $2050 \mathrm{~s}$.

Groundnut yields were significantly different both across sites $(P<0.001)$ and varieties $(P<0.05)$, Higher yields were recorded at the cooler site in both seasons (Tables 7.5 and 7.6). The yields were much low at the hotter site due to late start and premature end of both seasons which affected pod filling. In the first season, cowpea was affected by a fungal disease at the cool site (Mazowe) hence no grain yields were obtained. In the second season, both site and variety effects, and their interaction, were significant with the highest yields being recorded at the hotter site for all three cowpea varieties (Table 7.6). The results imply that groundnut, a crop

Table 7.4 Maize and sorghum grain yields at Kadoma (hot/wet) and Mazowe (cool/wet), Zimbabwe in the 2012/2013 season

\begin{tabular}{l|l|l|l|l|l|l}
\hline & \multicolumn{4}{l}{ Maize yield $\left(\mathrm{kg} \mathrm{ha}^{-1}\right)$} & \multicolumn{3}{l}{ Sorghum yield $\left(\mathrm{kg} \mathrm{ha}^{-1}\right)$} \\
\cline { 2 - 7 } & SC403 & SC513 & SC727 & Macia & SDSL89473 & Pato \\
\hline Kadoma & 2,202 & 1,848 & 1,552 & 3,164 & 2,085 & 1,595 \\
\hline Mazowe & 5,222 & 4,358 & 5,531 & 1,934 & 3,172 & 1,720 \\
\hline \multicolumn{2}{l}{} & $P$ value & SED & \multicolumn{2}{l}{$P$ value } & SED \\
\hline Site & $<0.001$ & 106.0 & 0.865 & 36.2 \\
\hline Variety & 0.002 & 129.8 & $<0.001$ & 44.3 \\
\hline Interaction & $<0.001$ & 183.6 & $<0.001$ & 62.7 \\
\hline
\end{tabular}


Table 7.5 Groundnut and cowpea grain yields at Kadoma (hot/wet) and Mazowe (cool/wet), Zimbabwe in the 2011/2012 season

\begin{tabular}{l|l|l|l|l|l|l}
\hline & \multicolumn{3}{l}{ Groundnut yield $\left(\mathrm{kg} \mathrm{ha}^{-1}\right)$} & \multicolumn{3}{l}{ Cowpea yield $\left(\mathrm{kg} \mathrm{ha}^{-1}\right)$} \\
\cline { 2 - 8 } & Nyanda & Natal common & Makhulu red & CBC1 & CBC2 & Landrace \\
\hline Kadoma & 158 & 355 & 140 & 1,250 & 1,546 & 976 \\
\hline Mazowe & 3,809 & 1,420 & 2,094 & - & - & - \\
\hline & & $P$ values & SED & \multicolumn{1}{l}{$P$ value } & \multicolumn{1}{l}{ SED } \\
\hline Site & $<0.001$ & 259 & - & & - \\
\hline Variety & 0.015 & 317.2 & - & & - \\
\hline Interaction & 0.007 & 448.6 & - & & - \\
\hline
\end{tabular}

Table 7.6 Groundnut and cowpea grain yields at Kadoma (hot/wet) and Mazowe (cool/wet), Zimbabwe in the 2012/2013 season

\begin{tabular}{|c|c|c|c|c|c|c|}
\hline \multicolumn{4}{|c|}{ Groundnut yield $\left(\mathrm{kg} \mathrm{ha}^{-1}\right)$} & \multicolumn{3}{|c|}{ Cowpea yield $\left(\mathrm{kg} \mathrm{ha}^{-1}\right)$} \\
\hline & Nyanda & Natal common & Makhulu red & $\mathrm{CBC} 1$ & $\mathrm{CBC} 2$ & Landrace \\
\hline Kadoma & 163 & 470 & 1,326 & 636 & 783 & 867 \\
\hline Mazowe & 662 & 603 & 1,027 & 306 & 692 & 514 \\
\hline & & $P$ value & SED & \multicolumn{2}{|l|}{$P$ value } & SED \\
\hline \multicolumn{2}{|l|}{ Site } & $<0.001$ & 36.4 & \multicolumn{2}{|l|}{0.018} & 94.1 \\
\hline \multicolumn{2}{|l|}{ Variety } & 0.007 & 44.5 & \multicolumn{2}{|l|}{0.086} & 115.3 \\
\hline \multicolumn{3}{|c|}{ Interaction $<0.001$} & 63.0 & 0.476 & & \\
\hline
\end{tabular}

which requires a relatively long season, will become less favorable in future as the temperature increases and rainfall reliability decreases. However cowpea will become more suitable as cooler wet areas become hotter.

\section{Grain Yields at the Drier Analogue Pair}

At the drier sites, maize yields were significantly higher $(P<0.001)$ at the cooler site (Matobo) in both seasons (Tables 7.7 and 7.8) although higher rainfall was recorded at the hotter site (Fig. 7.2). Variety and site by variety interaction effects

Table 7.7 Maize and sorghum grain yields at Chiredzi (hot/dry) and Matobo (cool/dry), Zimbabwe in the 2011/2012 season

\begin{tabular}{l|l|l|l|l|l|l}
\hline & \multicolumn{4}{l|}{ Maize yield $\left(\mathrm{kg} \mathrm{ha}^{-1}\right)$} & \multicolumn{3}{l}{ Sorghum yield $\left(\mathrm{kg} \mathrm{ha}^{-1}\right)$} \\
\cline { 2 - 7 } & SC403 & SC513 & SC727 & Macia & SDSL89473 & Pato \\
\hline Chiredzi & 75 & 150 & 245 & 26 & 185 & 15 \\
\hline Matobo & 2,523 & 2,152 & 3,450 & 2,374 & 2,337 & 1,781 \\
\hline \multicolumn{2}{l}{} & $P$ values & SED & \multicolumn{2}{l}{$P$ values } & SED \\
\hline Site & $<0.001$ & 445.4 & $<0.001$ & 173.5 \\
\hline Variety & 0.435 & 545.6 & 0.235 & 212.5 \\
\hline Interaction & 0.556 & 771.5 & 0.412 & 300.5 \\
\hline
\end{tabular}


Table 7.8 Maize and sorghum grain yields at Chiredzi (hot/dry) and Matobo (cool/dry), Zimbabwe in the 2012/2013 season

\begin{tabular}{l|l|l|l|l|l|l}
\hline \multicolumn{9}{l}{ Maize yield $\left(\mathrm{kg} \mathrm{ha}^{-1}\right)$} & \multicolumn{5}{l}{ Sorghum yield $\left(\mathrm{kg} \mathrm{ha}^{-1}\right)$} \\
\hline & SC403 & SC513 & SC727 & Macia & SDSL89473 & Pato \\
\hline Chiredzi & 469 & 270 & 266 & 1,133 & 967 & 348 \\
\hline Matobo & 3,648 & 2,844 & 2,310 & 3,131 & 1,662 & 1,543 \\
\hline & & $P$ value & SED & \multicolumn{2}{l}{$P$ value } & SED \\
\hline Site & $<0.001$ & 109.4 & 0.018 & 473.9 \\
\hline Variety & $<0.001$ & 134.0 & 0.155 & 580.4 \\
\hline Interaction & 0.004 & 189.5 & 0.544 & 820.7 \\
\hline
\end{tabular}

were only significant in the second season. Sorghum yields were also significantly $(P<0.05)$ higher at the cooler site, and variety and site by variety interaction effects were not significant (Tables 7.7 and 7.8).

Groundnut yields were higher at the cooler site in both seasons but the differences were only significant in the second season (Tables 7.9 and 7.10). Variety and site by variety interaction effects were not significant in both seasons (Tables 7.9 and 7.10). Cowpea yields were significantly $(P<0.001)$ higher at the cooler site except for the long season variety which was higher at the hotter site (Table 7.10). Variety and site by variety interaction effects were only significant in the second season.

Table 7.9 Groundnut and cowpea grain yields at Chiredzi (hot/dry) and Matopos (cool/dry), Zimbabwe in the 2011/2012 season

\begin{tabular}{l|l|l|l|l|l|l}
\hline \multirow{2}{*}{} & \multicolumn{3}{l}{ Groundnut yield $\left(\mathrm{kg} \mathrm{ha}^{-1}\right)$} & \multicolumn{3}{l}{ Cowpea yield $\left(\mathrm{kg} \mathrm{ha}^{-1}\right)$} \\
\cline { 2 - 8 } & Nyanda & Natal common & Makhulu red & CBC1 & CBC2 & Landrace \\
\hline Chiredzi & 170 & 431 & 298 & 255 & 94 & 27 \\
\hline Matobo & 410 & 432 & 416 & 857 & 1,167 & 1,153 \\
\hline & & $P$ value & SED & $P$ value & \multicolumn{2}{l}{ SED } \\
\hline Site & 0.303 & 110.2 & $<0.001$ & 156.0 \\
\hline Variety & 0.593 & 135.0 & 0.927 & 191.1 \\
\hline Interaction & 0.685 & 190.9 & 0.358 & 270.2 \\
\hline
\end{tabular}

Table 7.10 Groundnut and cowpea grain yields at Chiredzi (hot/dry) and Matopos (cool/dry), Zimbabwe in the 2012/2013 season

\begin{tabular}{l|l|l|l|l|l|l}
\hline \multicolumn{2}{l}{ Groundnut yield $\left(\mathrm{kg} \mathrm{ha}^{-1}\right)$} & \multicolumn{4}{l}{ Cowpea yield $\left(\mathrm{kg} \mathrm{ha}^{-1}\right)$} \\
\hline & Nyanda & Natal common & Makhulu red & CBC1 & CBC2 & Landrace \\
\hline Chiredzi & 344 & 332 & 272 & 640 & 639 & 653 \\
\hline Matobo & 520 & 467 & 385 & 982 & 1,032 & 380 \\
\hline & & $P$ value & SED & $P$ value & \multicolumn{2}{l}{ SED } \\
\hline Site & 0.009 & 45.4 & 0.001 & 36.5 \\
\hline Variety & 0.207 & 55.6 & $<0.001$ & 44.7 \\
\hline Interaction & 0.853 & 78.7 & $<0.001$ & 63.1 \\
\hline
\end{tabular}




\section{Discussion}

At the wetter analogue sites, higher maize and groundnut yields were recorded at the cooler site. The higher grain yields at cooler site can be attributed to higher effective rainfall due to lower evapo-transpiration, especially in the first season when rainfall amount and distribution between the sites were similar. The lower maize and groundnut yields at the hotter site (Kadoma) imply that these crops will have a reduced contribution to food security in the Mazowe (cooler) in 2050s climate which is predicted to be hotter. Sorghum and cowpea yields at the hotter site were relatively high despite the higher temperature, even in a low rainfall season, and therefore will be more suitable (than maize and groundnut) in predicted 2050s climate in Mazowe. Currently sorghum is mostly grown in the drier parts of Zimbabwe (Rao and Mushonga 1987). Therefore there is need to prepare farmers in Mazowe, and similar agro-ecological areas, to adapt their future cropping systems to more drought tolerant crops such as sorghum and cowpea in order to reduce the impacts of climate change on their food security and income status. This will involve ensuring the availability of suitable crops and varieties, relevant technical advice, policy and institutional arrangements to ensure a sustainable value chain.

At the dry sites yields for all crops were higher at the cooler site (Matobo) compared with the hotter site (Chiredzi). In the second season yields for sorghum (967-1133 $\mathrm{kg} \mathrm{ha}^{-1}$ for short and medium season varieties) and cowpea (639-653 $\left.\mathrm{kg} \mathrm{ha}^{-1}\right)$ at the hotter site were reasonable when compared to the national average $\left(<500 \mathrm{~kg} \mathrm{ha}^{-1}\right.$ for sorghum) but still lower than at the cooler site (Matobo) where rainfall was much lower (Tables 7.7 and 7.8). The results imply that under the predicted 2050s climate for Matobo crop production will become more risky and therefore threatening the already low food security status of smallholder farmers. Sorghum and cowpea appear to be more resilient but there is need to develop even more tolerant varieties and to also explore the introduction of new crops which can withstand the predicted higher temperatures. There is need to consider alternative livelihood options for areas with predicted 2050s climatic conditions similar to those currently prevailing in Chiredzi. Livestock farming, supported by supplementary fodder production to complement natural grazing is one such option. There is also need to explore other off-farm livelihood options.

In the absence of related field studies in SSA modelling provides an alternative comparison. The results of our study are in agreement with estimates based on Global Circulation Models (GCMs) and crop simulation models (e.g. Rosenzweig et al. 1993; Matarira et al. 1995). National cereal yields for the 2050s are estimated to decrease by between $2.5 \%$ and $30 \%$ with and without CO2 (Parry et al. 2004). Using the CERES-Maize model under the geophysical fluid dynamics laboratory (GFDL), and the canadian climate centre model (CCCM) which estimate $2-4{ }^{\circ} \mathrm{C}$ increases in Zimbabwe and precipitation changes ranging from \pm 10 to $15 \%$ on average during the October to April season (Unganai 1996; Matarira et al. 1995) projected maize yield declines particularly in dry-land farming in some Zimbabwean communities by 2050 . 
Although the analogue pair concept provides valuable insights into future crop production scenarios it has got considerable limitations. For example, although rainfall amount may be similar at two sites, spatial and temporal variations between the sites occur and these may affect crop yield. Current agro-ecological conditions at a particular site impose certain growth conditions which limit the extent to which yields can be directly compared with another site.

\section{Conclusions}

We conclude that as temperature increases due to climate change, more drought tolerant crops such as sorghum and cowpea will become important in ensuring food security of smallholder farmers at the studied sites. For the drier sites, even drought tolerant crops will be inadequate to ensure food security of the farmers prompting the need to explore other tolerant crops or varieties or pursue livestock production or off-farm activities. The hypothesis that short season varieties will perform better as temperature increases was not confirmed.

Acknowledgments We would like to acknowledge the Deutsche Gesellschaft fur Internationale Zusammenarbeit (GIZ) on behalf of the Federal Republic of Germany who sponsored the project "Adapting agriculture to climate change: Developing promising strategies using analogue locations in Eastern and Southern Africa" (CALESA-Climate Analogue Locations in Eastern and Southern Africa).

\section{References}

Bruns HA (2009) A survey of factors involved in crop maturity. Agron J 101:60-66

Carter TR, Jones R, Lu X, Bhadwal S, Conde C, Mearns L, O'neill B, Rounsevell M, Zurek M (2007) New assessment methods and the characterisation of future conditions. Cambridge University Press, Cambridge

Eriksen S, Aldunce P, Bahinipati CS, Martins RDA, Molefe JI, Nhemachena C, O'brien K, Olorunfemi F, Park J, Sygna L (2011) When not every response to climate change is a good one: identifying principles for sustainable adaptation. Clim Dev 3:7-20

Gregory PJ, Ingram JS, Brklacich M (2005) Climate change and food security. Philos Trans R Soc B Biol Sci 360:2139-2148

Matarira C, Makadho J, Mwamuka F (1995) Zimbabwe: climate change impacts on maize production and adaptive measures for the agricultural sector. Interim report on climate change country studies, US country studies program, Washington, DC

Nyabako T, Manzungu E (2012) An assessment of the adaptability to climate change of commercially available maize varieties in Zimbabwe. Environ Nat Resour Res 2:32

Parry ML et al (2004) Effects of climate change on global food production under SRES emissions and socio-economic scenarios. Glob Environ Change 14:53-67

Rao SA, Mushonga J (1987) A catalogue of passport and characterization data of sorghum, pearl milletand finger millet germplasm from Zimbabwe. A catalogue of passport and characterization data of sorghum, pearl milletand finger millet germplasm from Zimbabwe 
Rosenzweig C, Parry ML, Fischer, Frohberg K (1993) Climate change and world food supply. Research report no. 3. Environmental change unit. University of Oxford. pp 124

Unganai LS (1996) Historic and future climatic change in Zimbabwe. Clim Res 6:137-145

VSN (2011) GenStat for Windows, 14th edn. VSN International, Hemel Hempstead 